\title{
AMENDMENT AND REVISION OF STATE CONSTITUTIONS
}

\section{By Thomas RaEburn White $\dagger$}

Changes in the fundamental law of American states as laid down in their constitutions have been very numerous, especially within the last half century. The validity of some of these changes or proposed changes has been challenged in the courts; but in view of the controlling influence of public opinion, which in the last analysis must make the decision, the courts have been very liberal' in sustaining amendments or revisions, even though irregularly made, which have been approved by the people. This situation has led to some confusion of authority. A discussion of constitutional amendment and revision in the University of Pennsylvania Law Review is particularly timely in view of the prevailing agitation for a convention to revise the Constitution of Pennsylvania, which became effective on January 1,1874 , and to which fifty-three amendments have been made and many others proposed. ${ }^{1}$

Written constitutions setting up governments in the colonies were adopted in compliance with a resolution passed by the Continental Congress on May 15, 1776, as follows:

"Resolved, That it be recommended to the respective conventions of the united colonies, where no government sufficient to the exigencies of their affairs has been hitherto established, to adopt such government as shall, in the opinion of the representatives of the people, best conduce to the happiness and safety of their constituents in particular and America in general." 2

It is impossible in a brief article such as this to recount the experiences of the different colonies in following the advice given them by the Continental Congress, but, as the action taken in Pennsylvania was typical and gave rise to some of the legal questions hereafter to be considered, there will be a more detailed examination of Pennsylvania's constitutional history.

The first Constitution of Pennsylvania was prepared by a convention of delegates elected under the direction of an unofficial body ap-

$\dagger$ LL. B. 1899, University of Pennsylvania; B. L. 1896, LL. D. 1935, Earlham College. Member of the Philadelphia Bar. Author of Commentaries on tHe Constitution of Pennsylvania and of articles in various legal publications.

1. It is beyond the scope of this paper to review the experiences of constitution making and revision in all of the states of this country and the hundreds of decisions on various points involved, but a few fundamental principles may be profitably examined. (1825).

2. Proceedings Relative to Calling the Conventions of 1776 and 179037 
pointed by the Committees of Public Safety of the various counties of the province. This convention met in the State House at Philadelphia on July 15, 1776, under the chairmanship of Benjamin Franklin, and prepared a constitution which was declared to be effective without submission to the people. ${ }^{3}$ The committee which arranged for the election of delegates had no authority to do so, but the constitution enacted by this convention was accepted and acted under during the rather brief period of its existence. The initial constitutions of the various states were promulgated in much the same way. They were all revolutionary in character since none of them was the offspring of any previously existing government. ${ }^{4}$

Every constitution as originally adopted or later amended contains provisions furnishing the means whereby it may be amended. The great majority provide that specific amendments may be made through proposals by the legislatures and approval by vote of the people. Some, but not all, provide that conventions may be called for a general revision of the constitution. Only the Constitution of New Hampshire omits to provide for specific amendment, although it does provide a method whereby a convention may be called for a general revision. The most common method of making specific amendments is that of the present Constitution of Pennsylvania, which provides that a proposal for amendment must be passed by two legislatures and approved by vote of the people before becoming effective.

In several states, amendments may also be proposed by initiative petitions signed by a designated number of voters and submitted to the people without reference to the legislature. If approved, the amendments become part of the constitution. ${ }^{5}$ The details with respect to the manner in which such amendments may be proposed, advertised and approved vary in different states, but the effect is the same. It has been held, however, that authority to propose specific amendments does not permit a legislature to prepare a completely revised constitution and submit it to the people for adoption. Such a revision may be prepared only by a convention of delegates elected for the purpose. ${ }^{6}$

3. Id. at 45 and 66.

4. Many constitutions were irregularly adopted about the time of the Civil War. It is beyond the scope of this article to treat of them or of constitutions adopted by territories seeking admission as states.

5. These states are Arizona, Arkansas, California, Colorado, Michigan, Missouri, Nebraska, Nevada, North Dakota, Ohio, Oklahoma and Oregon. In Massachusetts an amendment may be proposed by an initiative petition, but also must be approved by the legislature.

6. Ellingham v. Dye, 178 Ind. 336, 99 N.E. 1 (1912) ; Livermore v. Waite, 102 Cal. 113, 36 Pac. 424 (1894). For a more complete discussion of this question with reference to the various provisions in constitutions of the different states, see Dod, The Revision and Anfendment of State Constitutions c. 4 (1910); Hoar, 
The constitutional method whereby specific amendments may be made must bercarefully followed ${ }^{7}$ because the legislature, or a group of electors signing an initiative petition, when proposing amendments to the constitution, is acting as an agent of the people, whose directions as contained in the constitution must be strictly observed. ${ }^{8}$ This power to propose amendments is not a legislative power; therefore, resolutions of the legislature proposing amendments to the constitution need not be approved by the governor although he has the power of giving or - withholding approval of ordinary acts of legislation..$^{*}$ If the constitution does not contain any provision whereby specific amendments may be proposed by the legislature or by initiative petition, no amendments may be proposed in those manners. These principles are well understood, and do not require further discussion.

It is now well settled by the weight of American authority that a provision in a constitution that specific amendments may be proposed by the legislature or by initiative petition is not an exclusive method of amendment but that the legislature may, whether or not authorized by the constitution, provide by law for the calling of a convention to

Constitutronal Conventions c. 6 (1917) ; Jameson, Constitutional Conventions c. 8 (4th ed. 1887).

There is, however, one instance in which the method condemned in Ellingham v. Dye, supra, was used. The legislature of Virginia provided that a commission of seven members should be appointed by the Governor to study the constitution and propose a detailed revision thereof. This was done, and the legislature under the power to propose specific amendments proposed that the constitution as revised and amended by this commission should become the constitution of the state. This constitution was approved by the people in 1928 without the calling of any convention. In Staples v. Gilmer, 183 Va. 613, 33 S.E.2d 49 (1945), the court referred to the manner in which this constitution had been adopted with apparent approval. This reference was, however, only dictum as the legality of the constitution of 1928 was not in issue.

Hooker, J., dissenting in the case of Carton v. Secretary of State, 151 Mich. 337,115 N.W. 429 (1908), said that where the legislature was permitted to propose amendments it could "practically submit a complete constitution entirely new without the intervention of a convention." This observation, however, is contrary to the weight of authority, and must be considered to be erroneous. See, however, Wheeler v. Board of Trustees, 200 Ga. 323, 37 S.E.2d 322 (1946).

7. Livermore v. Waite, supra note 6 ; Koehler v. Hill, 60 Iowa 543,14 N.W. 738 (1883) ; Com. v. Beamish, 309 Pa. 510, 164 At1. 615 (1932); Johnson v. Craft, 205 Ala. 386, 87 So. 375 (1921); Larkin v. Gronna, 69 N.D. 234, 285 N.W. 59 (1939) ; Barto v. Himrod, 4 Selden 483 (N.Y. 1833). If the proposals of specific amendments do not conform strictly to the powers conferred upon the legislature in that connection by the constitution, the courts will enjoin their submission to the people or even their operation, in clear cases, after the people have approved them. For an excellent discussion on this question see Dopd, op. cit. supra note 6 , at 209 et seq. and cases cited therein. See also HOAR, op. cit. supra note 6 , at $149,151$.

8. The same rule prevails where the people by a constitutional provision have delegated to the legislature the power to enact specific amendments without submission to the people. Eason v. The State, 6 Eng. 481 (Ark. 1851). There is no such provision at the present time.

9. Commonwealth v. Griest, $196 \mathrm{~Pa}$. 396, 410, 46 At1. 505, 508 (1900); Carton v. Secretary of State, 151 Mich. 337, 341, 115 N.W. 429, 431 (1908); Johnson v. Craft, 205 Ala. 386, 87 So. 375 (1921); JAMESON, op. cit. supra note 6 , at 586. See also Hollingsworth v. Virginia, 3 Dall. 378, 381 n. (U.S. 1798); Murphy Chair Company v. Attorney General, 148 Mich. 563, 112 N.W. 127 (1907). 
revise the constitution. ${ }^{10}$ It is a more difficult question whether, if a constitution provides a method whereby a convention may be called, it may be called in a different way. For example, if the constitution provides for the calling of a convention by a council of censors, as did the Pennsylvania constitution of 1776 , may the legislature act directly without regard to the action or non-action of the council of censors? Or, if the constitution provides that a constitutional convention may be called only after the people have approved such action by vote, may the legislature provide for the calling of a convention without submitting the question to the people?

The first constitution of Pennsylvania (1776) provided in its last section for the election of a Council of Censors, whose duty it should be to inquire whether the constitution had been "preserved inviolate," whether the legislative and executive branches of the government had exercised other or greater powers than they were entitled to under the constitution, whether public taxes had been laid and collected justly, and whether public moneys had been spent properly. If it found that the constitution had been infringed in the matters referred to, the Council was given power to call a convention by vote of two-thirds of its number, the convention to have the power to amend and revise the constitution. ${ }^{11}$

The Council of Censors met, but after a long and rather acrimonious debate adjourned without calling a convention as its advocates were unable to secure the necessary two-thirds vote. On March 24, 1789, the General Assembly passed by a substantial majority a resolution declaring that in the opinion of the House (then the only legislative body) alterations and amendments to the constitution of the state were immediately necessary and recommending that a convention

10. J AMESON, op. cit. supra note 6 , at 211-212, 388-389; State v. Dahl, 6 N.D. 81, 68 N.W. 418 (1896); Wells v. Bain, 75 Pa. 39 (1874); HoAR, op. cit. supra note 6 , at 48 . There is some expression of opinion to the contrary. Thus the Supreme Court of Massachusetts in an advisory opinion, 6 Cushing 573 (Mass. 1833), intimated that a constitution cannot be amended except in the manner provided therein. However, the court made a reservation: it said that it was not the understanding of the court that the House of Representatives had requested their opinion "upon the natural right of the people in cases of great emergency or upon the obvious failure of their existing constitution to accomplish the objects for which it was designed to provide for the amendment or alteration of their fundamental laws." This observation is interesting in connection with the discussion of the power of a legislature to provide for a constitutional convention although another method of calling a convention is provided by the constitution, or even in case it is forbidden. In another advisory opinion, 14 R.I. 649 (1883), the judges of the Supreme Court of Rhode Island said that the mode provided in the constitution for amendment is the only one which can be constitutionally used. These expressions of opinion, however, have been disregarded by later cases holding the contrary on this question. See Iit re Constitutional Convention, 55 R.I. 56, 178 At1. 433 (1935), in which the previous expression of opinion by Rhode Island judges was held erroneous. (1825).

11. Proceedings Retative to Calling the Conventrons of 1776 and 1790, 64 
should. be called for the purpose of "revising, altering and amending the Constitution of the State." 12 It also requested the Supreme Executive Council (at that time there was no governor) to promulgate this recommendation to the people in such manner as should seem most expedient. On September 15, 1789, the General Assembly, reciting that it had taken the opinion of the people (although in an informal way), and being satisfied that a majority of the people were desirous of exercising the right of self-government by revising the constitution, adopted a resolution to the effect that a convention to amend and revise the constitution should be called; that the convention should consist of the same number of persons as constituted the General Assembly, these persons to be elected in the same manner as members of the Assembly; and that it would be "expedient, just and reasonable that" the proposed constitution or amendments when prepared should be published four months before being confirmed to allow examination by the people. ${ }^{13}$ A large minority dissented vigorously to this action on two grounds: first, that the house, being "delegated for the special purpose of legislation," "was not competent to the subject"; and second, that the constitution itself provided a method of constitutional revision, which they deemed to be exclusive. ${ }^{14}$

The convention was duly organized, sat from November 24, 1789, until February 26, 1790, and then adjourned until August 9, 1790, in order that the constitution prepared by it might be published for the consideration of the people. The convention met again in August. made a few amendments to the draft as previously published, and adjourned sine die on September 2,1790, after providing the "order of procession for the proclamation of the Constitution of the Commonwealth of Pennsylvania." ${ }^{15}$ This constitution was never submitted to the people for approval. In explaining its action in ignoring the provision of the Constitution of 1776 , the General Assembly recited that the mode of proceeding by the Council of Censors was "not only unequal and unnecessarily expensive but too dilatory." 16

12. $I d$. at 129 .

13. Id. at 133-136. One of the leading members of the Assembly, William Lewis, objected to the provision fixing the time during which the amendments and aiterations should be published as he thought such matters should be determined by the convention itself. It might think more or less time was desirable, and should not be controlled by the legislature because, he said, "The convention must be chosen by the people in whom alone the authority is lodged and will derive all powers from them. They will set, and they ought to act, both as to adjournments and in all other respects independent of this house and should not in the one case any more than in others be influenced by it."

14. $I d$, at 136 .

15. Id. at $295-296$.

16. $I d$. at 133 . 
This Pennsylvania convention, as well as similar ones in Delaware and Maryland, is considered illegitimate by Judge Jameson. ${ }^{17}$ However, it may be said in opposition to his view that as the supreme power of government resides in the body of the people and always remains there, ${ }^{18}$ they may act otherwise than as provided in the constitution if the means provided therein prove to be unworkable. It was said in an advisory opinion of the Supreme Court of Massachusetts ${ }^{19}$ that "upon the obvious failure of their existing constitution to accomplish the objects for which it was designed," the people might "provide for the amendment or alteration of their fundamental laws." 20 On principle, it would seem to follow that even if the constitution should provide that no convention could be called, except after a favorable vote of the people, it could be called by the legislature in an emergency without submitting the question to the people. Since the supreme power always remains with the people and is never surrendered by them, even temporarily, it might be held that they would have the power to act through the legislature as their agent notwithstanding their previous restriction of the legislature's power. It is very doubtful whether such a question will ever arise, as a positive prohibition in the constitution would probably be observed both by the legislature and by the people acting through an initiative petition.

An interesting case which has a bearing on this point is Bennett v. Jackson. ${ }^{21}$ An act passed by the Indiana General Assembly in 1913 had submitted to the electors of the state at the general election of 1914 the question whether a constitutional convention should be called, and they had voted against it. Three years later the legislature, ignoring this vote and not resubmitting the question to the people, provided for the calling of a convention. The majority of the court held that the Assembly could not call a convention in any case without first submitting the matter to the voters of the state and receiving an affirmative answer and that, therefore, the Assembly could not call a convention against the will of the people as expressed in the earlier vote. The

17. JAMESON, op. cit. supra note 6 , at 216 .

18. See remarks of James Wilson in Pennsylvania debates on adoption of Federal Constitution, 2 Elliot's DeBates 433, 459 (2d ed. 1836), and his opinion in Chisholm v. Georgia, 2 Dall. 419, 457 (U.S. 1793).

19. See note 10 supra.

20. 6 Cushing 573 (Mass. 1833). Thirty-four states now contain provisions in their constitutions which provide both for specific amendments in the manner above described and also a method whereby conventions may be called by action of the legislature. These states are Alabama, Arizona, California, Colorado, Delaware, Florida, Georgia, Idaho, Iowa, Kansas, Kentucky, Maryland, Michigan, Minnesota, Missouri, Montana, Nebraska, Nevada, New Hampshire, New Mexico, New York, North Carolina, Ohio, Oklahoma, Oregon, South Carolina, South Dakota, Tennessee, Utah, Virginia, Washington, West Virginia, Wisconsin, and Wyoming.

21. 186 Ind. 533, 116 N.E. 921 (1917). 
court's opinion seems to have been based mainly upon what it erroneously thought was a universal custom to submit to the people the question whether a convention should be called before actually calling it. There was a very able dissenting opinion which, it is submitted, expresses the correct view. This opinion pointed out that the Constitution of Indiana did not prescribe the manner in which a convention should be called or provide that the people must first approve it, and maintained that the court had no authority to restrict the action of the Assembly, which was the only department "authorized to speak for the people upon this subject and to point out a mode for the expression of their will." The dissenting opinion further maintained that the popular vote against a convention was to be considered by the Assembly, but could not prevent it, as the agent of the people, from calling a convention.

Where the constitution expressly provides that the legislature cannot call a convention until a favorable vote has been received, it may be said that, except in case of an emergency, this restriction would be observed by the legislature. However, the vote of the people in any such case is not a positive command to the legislature to call a convention, ${ }^{22}$ nor does it restrict the convention's power unless the act submitting the question to the people contains provisions which limit the convention to amending one or more designated sections of the constitution or prohibit it from amending others.

It has become quite common for the legislature before calling a convention to submit to the people the question whether such a convention should be called, for the vote of the people is an indication whether they would approve amendments if made. Since a vote against a convention would suggest that its work might be rejected, it is in the interest of economy that the will of the people should be ascertained, if possible, before the convention is actually called together. The statement in the majority opinion in Bennett $v$. Jackson ${ }^{23}$ that in no case can a convention be called unless the people have voted in favor of it is clearly erroneous. There are no authorities which sustain this view. As the dissenting opinion in Bennett $v$. Jackson indicates, if the constitution contains nothing on the subject, the power of the legislature in this respect is unlimited.

It is, therefore, apparent that the people have wide latitude in determining how they shall exercise their reserved power to change

22. In three states, New York, Michigan and Missouri, after a favorable vote of the people, the convention assembles without further action of the legislature, de- tails of the election of delegates being contained in the constitution itself.

23. 186 Ind. 533, 116 N.E. 921 (1917). See also JAMEson, op. cit. supra note 6, at $600-601$. 
the fundamental law. Of course, they cannot do it in a spontaneous manner, but only through some agent authorized to speak for all of them. ${ }^{24}$ In Wells v. Bain ${ }^{25}$ the Supreme Court of Pennsylvania said:

"When a law becomes the instrumental process of amendment it is not because the legislature possesses any inherent power to change the existing constitution through a convention, but because it is the only means through which an authorized consent of the whole people of the entire state can be lawfully obtained in a state of peace." 26

It may be added that in states having the initiative and referendum a petition filed by a certain percentage of the voters may become "the instrumental process of amendment."

In three states, Michigan, New York and Missouri, the constitution itself directs that at stated intervals an election shall be held to determine whether a convention shall be called, and if the vote is favorable the convention shall be held without further action by the legislature. The constitution also provides the manner in which the delegates shall be elected, the powers which the convention shall have with respect to its organization, etc., but imposes no limitations on the convention's authority except that proposed amendments must be submitted to the people for approval. Legislative action in these states is required merely to submit to the voters the question whether a convention shall be called.

A question then arises as to the powers of such a convention. Is it omnipotent (except as controlled by the Constitution of the United States), or is it limited by the terms of the act or the constitutional provision whereby it was called into existence or by some other authority?

There are expressions of opinion, worthy of consideration, that a convention lawfully called to revise the constitution of a state is sovereign, and not subject to any restraint which may have been contained in the laws calling it into existence. Thus in the New York constitutional convention of $1821 \mathrm{Mr}$. Livingston, one of the delegates, in reply to an argument that the powers of the convention were limited said:

24. An attempt to establish a constitution by a convention not called by the legislature but chosen through spontaneous action by the people gave rise to Dorr's Rebellion in Rhode Island. The opinion of the Supreme Court of the United States in Luther v. Borden, 7 How. 1 (U.S. 1849), clearly demonstrates that a convention cannot be legally called in that manner.

25. 75 Pa. 39 (1873).

26. $I d$. at 47. 
"Sir, the people are here themselves. They are present by their delegates. No restriction limits our proceedings . . .. Sir, we are standing upon the foundations of society." 27

This question was debated at length in the Pennsylvania convention of 1873. The act calling the convention and providing for the election of delegates had stipulated that it should have only certain powers and no others. The prevailing view of the convention was that these restrictions could be disregarded, particularly in view of the fact that when the question whether a convention should be called had been submitted to the people they had voted in favor of it. Mr. Ellis, one member of the convention, argued:

". . . when the Legislature passed an act submitting the question to the people whether the Convention should assemble or not for the purpose of amending the Constitution of the State, and that question was submitted to the people, the only remaining business for the Legislature to do was to provide the means necessary for the assembling and organization of this Convention. Look at it. If the Legislature had the power to say, 'you shall not touch the article upon the Declaration of rights,' the Legislature had the power to say, 'you shall not touch the judiciary article.' If they had the power to say, 'you shall not touch these two articles,' they had power to say, 'you shall not touch but one article of the Constitution,' and thus nullify the formal judgment of the people." 28

The contrary view was also presented, especially by Judge Black, former Attorney General of the United States, who argued that the act calling the convention limited its power. ${ }^{29}$ Subsequently the convention adopted the Ellis view by formal resolution as follows:

27. There are other expressions of opinion worthy of note. In 1837 the Hon. George M. Dallas, of Pennsylvania, prior to the meeting of the constitutional convention of 1837, wrote that in his opinion the convention when assembled would "possess, within the territory of Pennsylvania, every attribute of absolute sovereignty, except such as may have been yielded and are embodied in the Constitution of the United States." In the Illinois convention of 1847, one delegate argued: "We are the sovereignty of the State. We are what the people of the State would be, if they were congregated here in one mass meeting. We are what Louis XIV said he was, 'We are the State.' We can trample the Constitution under our feet as waste paper, and no one can call us to account save the people." JAMESON, op., cit. supra note 6 , at 303 .

28. 1 Debates of the Constitutional Convention 53 et seq. (1873).

29. Judge Black said: "Suppose the Legislature had seen proper to say that we should not assemble at all, or that we should make no amendments to the Constitution-that the Constitution should stand just as it is; then the question is, whether we could, in defiance of that mandate, assemble ourselves together in Convention, representing, as we do, the whole people of the Commonwealth, and against the will of the people, and against the authority of the organized government now existing, proceed to alter the body of it. I say we could not do that. That would be revolutionary. Where do we get the power? Where does it come from? Nobody will deny that we are sitting here in pursuance of certain acts of the Legislature-one 
" Resolved, That the constitution of the state is the only recognized form of its government, and the people having expressly reserved to themselves the right to alter, reform, or abolish their government in such manner as they think proper, and having in distinct terms excepted this right out of the general powers of government and declared that such right shall forever remain. inviolate, this convention deems it to be its duty to declare that it is not within the power of any department to control the powers of a convention called by the people to reform their constitution, and that the convention, subject to the Constitution of the United States, is answerable only to the people from whom it derived its power.'" 30

Neither of these arguments expresses the correct doctrine. The power of the convention does not come from the legislature as argued by Judge Black; it comes from the people and can be limited by them. ${ }^{31}$ In Woods's Appeal, ${ }^{32}$ the court held in part as follows:

"A convention has no inherent rights; it exercises powers only. Delegated power defines itself. To be delegated it must come in some adopted manner to convey it by some defined means. This adopted manner therefore becomes the measure of the power conferred. The right of the people is absolute in the language of the bill of rights, 'to alter, reform or abolish their government in such manner as they may think proper.' This right being theirs, they may impart so much or so little of it as they shall deem expedient. It is only when they exercise this right, and not before [that] they determine by the mode they choose to adopt, the extent of the powers they intend to delegate. Hence the argument which imputes sovereignty to a convention, because of the reservation in the bill of rights, is utterly illogical and unsound. The bill of rights is a reservation of rights out of the general powers of government to themselves, but is no delegation of power to a convention." 33

The court continued that the popular vote meant nothing more than approval of the calling of a convention, but that when the legislature passed an act providing for the call of the convention and the delegates were elected by the people pursuant to the terms of that act, they thereby conferred upon the convention the powers which the said act

which first authorized a vote by the people upon the question, and the other one which authorized the election of delegates to the Convention. If we derive our power from that source, is it possible that we can take it without the limitations that were imposed upon it by those who created it? I don't think that question can be answered in any but one way." 1 Debates of the Constitutionat Convention 157 (1873).

30. $8 I d$. at 745 .

31. See, however, JAMESON, op. cit. supra note 6 , at 414, apparently expressing a contrary opinion.

32. $75 \mathrm{~Pa} .59$ (1874)

33. Id. at $69-70$. 
indicated they should have and no more. As the act of the Assembly according to which the delegates were elected provided that the Bill of Rights should not be changed in any manner and that the work of the convention should be submitted to the people in a certain way, it must be considered that the delegates were elected with that understanding; consequently, the convention was limited accordingly. ${ }^{34}$ The Supreme Court of Pennsylvania, in Wells v. Bain, ${ }^{35}$ pursuant to this theory, enjoined the holding of an election to determine the approval or disapproval of the work of the convention in a manner different from that prescribed by the act of the Assembly.

Judge Jameson, apparently not approving the theory of the Pennsylvania court, seems to argue that conventions are subject to the control of the legislature calling them. ${ }^{36}$ Dodd criticizes these views as going too far. He believes that the constitutional convention is a "regular organ of the State . . . neither sovereign nor subordinate to the legislature but independent within its proper sphere." 37

It is submitted that neither of these authors states the correct theory of the relation between the convention and the legislature. The views expressed by the Supreme Court of Pennsylvania in Wells $v$. Bain, ${ }^{38}$ and Woods's Appeal, ${ }^{39}$ seem to be supported by the better reasoning: the convention is not subordinate to the legislature, but if the legislature in calling the convention provides that it shall be restricted in power, and delegates are elected pursuant to the act, the restraint on the power of the convention is really imposed not by the legislature but by the people. That the legislature does not have control of the convention is demonstrated by the fact that there are no cases which sustain any legislative action limiting the convention in any way after it has been called together. The correct principle appears to be that there are no limitations on the power of a convention except those imposed by the people themselves, either by approving an act proposing to call a convention with limited powers or in connection with the election of delegates. ${ }^{40}$

34. HOAR, op. cit. supra note 6 , criticizes this decision on the ground that it does not accord with the facts. He apparently is of the opinion that the election of a delegate pursuant to an act of assembly limiting the powers of a convention does not involve an approval of this limitation by the people. It is submitted, however, that the view of the Supreme Court of Pennsylvania is the better one.

35. $75 \mathrm{~Pa} .39$ (1873).

36. JAMESON, op. cit. supra note 6 , at 356 et seq.

37. DoDd, op. cit. supra note 6 , at 80 .

38. $75 \mathrm{~Pa} .39$ (1873).

39. 75 Pa. 59 (1874).

40. See opinion of the judges of the Supreme Court of New York, reported in JAmeson, op. cit. supra note 6, at 663 . See also Sproule v. Fredericks, 69 Miss. 898,11 So. 472 (1892); McMullen v. Hodge, 5 Tex. 34 (1849). 
It may also be stated as a general principle that the convention is independent of any restrictions on its power contained in a previous constitution, such as a provision that the bill of rights should never be changed. The very purpose of a convention is to revise and amend the previous constitution, and nothing therein contained can prevent its doing so if the people have conferred plenary power upon the convention.

In this connection, however, a distinction should be made between directions contained in a previous constitution with respect to the manner in which amendments may be made or a convention called and restrictions on the power of the convention itself with respect to the amendments or revisions which it may make. As has been pointed out, constitutional provisions with respect to the manner in which specific amendments may be made or conventions may be called must be followed unless under existing circumstances this course of action appears to be impossible or at least impracticable. However, no matter what its provisions may be, a constitution cannot prevent the people, in whom the supreme power always remains, from amending or revising it in such manner as they may determine, either through specific amendments or by means of a convention. In Livjermore v. Waite, the court said:

“. . . the constitution provides two methods by which changes may be effected in that instrument, one by a convention of delegates chosen by the people for the express purpose of revising the entire instrument, and the other through the adoption by the people of propositions for specific amendments that have been previously submitted to it by two-thirds of the members of each branch of the legislature. It can be neither revised nor amended except in the manner prescribed by itself, and the power which it has conferred upon the legislature in reference to proposed amendments, as well as to calling a convention, must be strictly pursued. Under the first of these methods the entire sovereignty of the people is represented in the convention. The character and extent of a constitution that may be framed by that body is freed from any limitations other than those contained in the constitution of the United States." 41

The act of the legislature in proposing specific amendments is not legislative in character and does not require the approval of the governor. There is no definite ruling that the act calling a convention need not be approved by the governor, ${ }^{42}$ and there are instances in which

41. 102 Cal. 113, 117, 36 Pac. 424, 425 (1894).' See also Larkin v. Gronna, 69 N.D. 234, 285 N.W. 59 (1939); Downs v. City of Birmingham, 240 Ala. 177, 198 So. 231 (1940).

433 (1908). 
such approval has been given. Although the question is a very narrow one, it would seem that an act of legislation providing for a convention contains so many provisions of a legislative character that it should be approved by the governor, although it is hardly possible that the governor could block the calling of a convention if the legislature, acting as the agent of the people, desired to call it. The practice seems to be that the governor signs bills of this character. ${ }^{43}$ Whether he could prevent the calling of a convention by vetoing the bill must await the determination of the courts if such a case arises. ${ }^{44}$

Many constitutions provide that any amendments proposed by a convention shall have no validity until approved by the people. ${ }^{45}$ In the absence of any such provision, either in the old constitution or in the act calling the convention, it was held in Staples $v$. Gilmer ${ }^{46}$ that a convention can enact an amendment without submitting it to the people. The Constitution of Virginia at that time provided that the legislature could call a convention without any restriction of its powers or as to the manner in which it could be called. The legislature called a convention for the sole purpose of changing the qualifications of electors so as to permit soldiers to vote. In order to save time, the convention met, made the desired amendment, and immediately declared it to be operative without submitting it to the people. This action was sustained by the court in a well-considered opinion.

Jameson argues ${ }^{47}$ strongly that the view of this case would make the convention a despot; that it would be better to have an absolute monarch because his rule would be "' 'tempered,' if not otherwise, 'by assassination,' into a sort of practical responsibility to the people"; that "to entrust such a body, without check, with the enactment of its fundamental law, would be but to discount the national life,- to antedate that final overthrow which history shows to be in store for all

43. But see the Constitutions of Alabama and Delaware, which provide that resolutions proposing amendments or calling a convention shall not be submitted to the Governor for approval.

44. See an interesting discussion in Hutcheson v. Gonzales, 41 N.M. 474, 71 P.2d 140 (1937).

45. Arizona, California, Colorado, Idaho, Maryland, Michigan, Missouri, Montana, Nebraska, New Hampshire, New Mexico, New York, Ohio, Oklahoma, Utah, Washington, West Virginia, Wyoming.

46. 183 Va. 613, 33 S.E.2d 49 (1945). As shown above, the Pennsylvania Convention of 1789 promulgated the Constitution of 1790 without submitting it to the people. See also Loomis v. Jackson, 6 W. Va. 613 (1873). Dond, op. cit. supra note 6 , at 64-66, mentions several other instances in which constitutions were enacted by conventions without submission to the people, but some of them were reconstruction constitutions. The Constitution of Alabama, $\$ 286$, appears to give a convention full power to make any changes in the constitution it may agree upon without submission to the people.

47. JAMEson, op. cit. supra note 6 , at 415 . 
nations." As support, he cites Parker v. Commonwealth ${ }^{48}$ which, however, related only to the validity of a local option law and has since been overruled.99

It is submitted that Judge Jameson's view is too extreme and not in accordance with the best authority. If the people elect delegates to a convention that is authorized to revise the constitution without limitations, it would seem that the convention is restrained only by the Constitution of the United States.

Thus far we have discussed the power of a constitutional convention legally called to revise the constitution. Such power relates strictly to changes in the fundamental law, which where they have to be submitted to the people are of no validity until approved by them. There is, however, the further question whether the convention has any ordinary power of legislation. It may be stated as a general principle that it has not. A convention is called together for the exclusive purpose of proposing or making changes in the fundamental law which, when they become effective, will control the legislature and other organs of the government. It clearly has no further powers, and if it attempts to interfere with the existing departments of government, legislative, executive or judicial, or to perform their functions, it goes beyond its authority. Even where it is under no limitations and its proposals need not be approved by the people, it has no legislative or executive power. There have been, however, a number of instances in which conventions have attempted, in effect, to legislate through "ordinances." On principle, such "ordinances" are not within the powers of the convention and ordinarily have been held void, but political considerations enter into the decisions to such extent that the cases are in much confusion. ${ }^{50}$

Particularly in recent years, some conventions have included in proposed constitutions provisions which are really legislative in character. When these proposals have become a part of the constitution, they are, of course, binding on the people of the state. This tendency is unfortunate, as provisions of this. kind do not properly belong in a constitution. $^{51}$ Legislative provisions contained in a constitution are,

48. $6 \mathrm{~Pa} .507$ (1847).

49. Locke's Appeal, $72 \mathrm{~Pa} .491$ (1873).

50. It would serve no useful purpose to review the many instances where legislation or interference with the executive department has been attempted. They are collected by HOAR, op. cit. supra note 6, c. 11. In most instances the courts held such action void.

51. Several constitutions which have been adopted or amended in recent years are very long and contain many provisions which are legislative in character. In the compilation entitled Constitutions of THE STATES AND UNITED STATES, published in 1938 by the New York State Constitutional Committee, the Constitution of California covers 96 pages, the Constitution of Louisiana 130 pages, the Constitu- 
of course, not repealable by the legislature. This leads to difficulties where changes of condition require, or at least make desirable, changes which the legislature cannot make.

A convention, however, does have power to provide for its own organization and accommodations, such as a meeting place; to provide for the appointment and compensation of its own officers and employees; and to provide for the printing and preservation of its records. In the absence of any limitation on its power in this respect, the convention may also make the necessary arrangements for submitting to the people the question whether or not its work shall be approved, ${ }^{52}$ and may adopt a schedule for putting the constitution into effect. In Goodrich v. Moore, a state printer disputed the right of the convention to appoint a competitor to print the records of the convention. The court said that this matter was within the power of the convention:

"But even had the Legislature intended and attempted to claim and exercise the act of providing a printer for the Constitutional Convention it would have been unauthorized and unwarrantable interference with the rights of that body. The admission of such a right in the legislature would place the Convention under its entire control leaving it without authority even to appoint or to elect its own officers, or adopt measures for the transaction of its legitimate business . . . . It is the highest legislative assembly recognized in law, vested with the right of enacting or framing the supreme law of the State. It must have plenary power for this and over all the incidents thereof." 53

There is some difference of opinion on the question of drawing money from the state treasury for the expenses of the convention. As the treasurer is under the control of the officers of the state under the old constitution, some authorities maintain that the convention cannot actually obtain money from the treasury except with the cooperation of the existing officials. ${ }^{54}$ However, it is interesting to note that the president of the Pennsylvania Convention of 1789 drew a warrant on the state treasurer for 100 pounds for the expenses of the convention. ${ }^{55}$

tion of Oklahoma 74 pages. Some of the older constitutions, e.g., that of Connecticut, occupy only 16 pages of the same volume. These Constitutions, as well as others which are almost as long, contain provisions about many things which are properly legislative in character: for example, regulations of primary elections; detailed provisions with respect to the initiative and referendum; provisions relating to retirement pensions, horse racing, boxing and wrestling; regtlations of public utilities; regulations of liquor traffic; and regulations of many other matters too numerous to mention.

52. JAMESON, op. cit. supra note 6, at 423 et seq.; DoDd, op. cit. supra note 6, c. 3; Hutcheson v. Gonzales, 41 N.M. 474, 71 P.2d 140 (1937); Opinion of the Justices, 76 N.H. 612 (1889).

53. 2 Minn. 61, 66 (1858).

54. E.g., Hutcheson v. Gonzales, 41 N.M. 474, 71 P.2d 140 (1937).

55. Procegdings Relating to Conventions of 1776 and 1790, 144 (1825). 
The validity of this act never came before the courts. The general rule appears to be that a convention has no inherent power to draw money from the state treasury, but must depend on the legislature to make an appropriation for its expenses and to authorize that the money may be drawn by warrants signed by the president or some other officer of the convention..$^{56}$

A very important question which arises in connection with the holding of constitutional conventions is who are entitled to membership in such conventions and how must the delegates be chosen. The justices of the Supreme Court of Rhode Island in an advisory opinion to the governor said:

"A constitutional convention is an assembly of the people themselves acting through their duly elected delegates. The delegates in such an assembly must therefore come from the people who choose them for this high purpose and this purpose alone. They cannot be imposed upon the convention by any other authority. Neither the legislature nor any other department of the government has the power to select delegates to such a convention. The delegates elected by and from the people, and only such delegates, may and of right have either a voice or a vote therein." "No one, not a delegate, no matter how exalted his station in the existing government, can be assured either a voice or a vote in such a convention unless he comes there with a commission from the people as their delegate, although the convention itself may if it please invite him to address it or give it counsel, in which case he will be in the convention by invitation and not by virtue of his office." 57

It is submitted that this statement is sound. A constitutional convention represents the people, and its delegates should be elected by the people.

Efforts to revise a constitution by commission or to influence the work of a convention by this means have not met with any great degree of approval. A commission appointed by the governor or some other officer of the state is not a convention, and, however ably its work may be done, it does not ordinarily commend itself to the people. In 1919, the legislature of Pennsylvania provided for the appointment by the governor of twenty-five citizens of the Commonwealth to constitute a Commission on Constitutional Amendment and Revision. ${ }^{58}$ Any

56. See Jameson, op. cit. supra note 6 , at 436 et seq., and 7 DeEates of THE Convention to Amend the Constitution of Pennsylvania 696 et seq. (1873).

57. In re The Constitutional Convention, 55 R.I. 56, 97-98, 178 Atl. 433, 452 (1935). There are other expressions of opinion all in harmony with the one quoted above: Wells v. Bain, $75 \mathrm{~Pa} .39,52$ (1874); Livermore v. Waite, 102 Cal. 113, 36 Pac. 424 (1894) ; Ellingham v. Dye, 178 Ind. 336, 99 N.E. 1 (1913).

58. Act of June 4, 1919, P.L. 388. 
vacancies in the Commission were to be filled by the governor. It was provided that the Commission

"should study comprehensively and in detail the provisions of the present constitution in the light of modern thought and conditions with a special view to the necessity or advisability of changing or admitting any such provisions in order to obtain and secure for the people of this Commonwealth a form of government best suited to their needs and most conducive to their welfare." 59

The Commission also was directed to determine whether a revision should be made by convention or by revising particular sections. It was duly appointed, was in session several months, and proposed one hundred eighty-four amendments and the calling of a convention to make a comprehensive revision. Its proceedings are fully reported in four volumes. ${ }^{60}$ In $1921{ }^{61}$ the legislature provided that at the primary election that year a vote should be taken to determine. whether a constitutional convention should be held and that, if the vote were favorable, three delegates should be elected from each congressional district within the Commonwealth and twenty-five delegates at large appointed by the governor. The act further provided that it should be the duty of the convention "to consider the constitution recommended by 'the Commission on Constitutional Amendment and Revision." "At the subsequent primary election, the proposal to call a convention under this act was defeated. The fact that twenty-five delegates were to be appointed by the governor instead of being elected by the people may have been a contributing cause. If a convention had been called pursuant to this act, its legality would have been open to serious question.

Efforts in other jurisdictions to revise constitutions by the work of commissions also have been rather unsuccessful. Commissions to propose amendments or revisions have been appointed in New York, Michigan, Maine, New Jersey and Rhode Island. ${ }^{62}$ In Michigan, New Jersey and Rhode Island, the commissions prepared completely revised constitutions which the people rejected. However, in some cases recommendations of the commissions were accepted by the people after modification by the legislature. ${ }^{63}$ In other cases, amendments have been

59. Ibid. (1920).

60. Entitled Commission on Constitumtonal Amendment and Revision

61. Act of April 27, 1921, P.L. 323.

62. JAMTESON, op. cit. supra note 6 , at 570-575.

63. The work of the Virginia Commission referred to in Staples v. Gilmer, supra note 46 , was sustained only because of approval by the people and long acquiescence before it came before the courts. 
suggested by unofficial committees of citizens, accepted by legislatures, and, usually after revision, submitted to the people for approval. ${ }^{\text {44 }}$

The necessity of having delegates who come directly from the people is so great that it has even been doubted whether the convention has power to fill vacancies in its membership caused by death or resignation. ${ }^{65}$ The doubt is based principally on the unchallenged fact that the legislature would have no power to appoint delegates and, therefore, could not do it indirectly by delegating this power to the convention when vacancies occurred. In the Pennsylvania Convention of 1873 , one argument against the theory that the convention had supreme power was the fact that many of its members had not been elected by the people but had been appointed by the other delegates to fill vacancies. ${ }^{68}$ Jameson remarks that the absence of one or more delegates is not a serious evil and that it might be better to leave the vacancy unfilled than to have a delegate chosen in an illegal manner. However, the question of filling vacancies is on the borderline between legislative power and constitution-making power. Acts calling conventions in most cases have provided methods for filling vacancies; a common practice is to select the new delegate from the same district from which came the delegate who has died or resigned. In view of the inconvenience which would result otherwise, it is probable that the courts would sustain an act which provided for the election of delegates by the people and for the filling of vacancies by the convention itself through issuance of writs for a new election or by appointment from the district which the former delegate represented.

Finally we come to the question of the extent to which the courts will interfere with irregular amendments or revisions of a constitution. It has already been noted that the legislature (or a group of citizens where the initiative and referendum may be used) must comply strictly with the provisions of the constitution as to the manner in which specific amendments may be proposed. ${ }^{67}$ If directions of the constitution are not followed, the courts have jurisdiction to interfere. In Ellingham v. Dye, ${ }^{68}$ the court said:

"Whether legislative action is voided for want of power in that body or because the constitution's forms or conditions have not been followed or have been violated may become a judicial question and upon the courts the inevasible duty to determine it falls.

64. The recent amendment of the Constitution of Pennsylvania providing for consolidation of the City and County of Philadelphia was prepared by committees of citizens.

65. JAMrEson, op. cit. supra note 6 at 331,333 .

66. See Wells v. Bain, $75 \mathrm{~Pa} .39,52$ (1873).

67. Ibid.

68. 178 Ind. $336,391,99$ N.E. 1, 21 (1912). 
And so the power resides in the courts and they have with practical uniformity exercised the authority to determine the validity of proposal, submission, or ratification of changes in the organic law."

In some cases it has been argued that any question as to the validity of a constitutional amendment is a political one and thus beyond the jurisdiction of the courts, but this view has not been accepted. There is no question whatever that the courts may intervene before the proposed amendment has been approved by vote of the people; there is some difference of opinion as to whether they may do so after the amendment has been approved, but it is believed that the correct rule is the one expressed in the opinion just quoted. ${ }^{69}$ It may be added, however, that the courts have very properly taken the position that after an amendment has been approved by the people every intendment will be resolved in favor of its validity. ${ }^{70}$

When the case involves the validity of the action of a convention the judicial attitude is somewhat different. The courts are slow to interfere with the convention's action. Usually, they will not intervene while the convention is in session, even though its proceedings might be deemed unlawful. However, after the convention has finished its work and prior to approval by the people, that work becomes subject to the action of the courts.

In Carton $v$. Secretary of State, ${ }^{71}$ it was held that a constitutional convention could not submit its work to the vote of the people at a time different from that which had previously been fixed by the old constitution. A similar decision was Wells $v$. Bain ${ }^{72}$ where the court enjoined the submission of the work of the Pennsylvania Convention of 1873 to the people in the manner the convention had fixed by ordinance, that method being contrary to the one prescribed by the enabling act.

69. See also Collier v. Frierson, 24 Ala. 100, 109 (1854), in which the court said: "We entertain no doubt that to change the constitution in any other mode than by convention, any requisition which is demanded by the instrument itself must be observed and the omission of any one is fatal to the amendment."

This rule has been held to cover the counting of the votes. See Rich v. Board of State Canvassers, 100 Mich. 453, 59 N.W. 181 (1894); McConnaghy v. Secretary of State, 106 Minn. 392, 119 N.W. 408 (1909).

70. See DoDd, op. cit. supra note 6 , at 217 , where the author observes that when the courts are opposed to the amendment, they not infrequently find some reason for declaring that it has been invalidly adopted. For the proposition that the courts will ordinarily resolve doubt in favor of the validity of amendments which have been approved by the people, Dodd cites State ex rel. Thompson v. Winnett, 78 Neb. 379, 110 N.W. 1113 (1907); State v. Laylin, 69 Ohio St. 1, 68 N.E. 574 (1903); May and Thomas Hardware Co. v. Birmingham, 123 Ala. 306, 26 So. 537 (1899).

71. 151 Mich. 337, 115 N.W. 429 (1908).

72. 75 Pa. 39 (1873). 
Although the courts ordinarily will not interfere with a constitutional convention while it is in session, a case might arise which would require judicial intervention. If a convention should be illegally constituted (e.g., if delegates were appointed instead of being elected as required by law or if the legislature were to resolve itself into a constitutional convention), it would seem clear that the proceedings of that convention should be restrained by the courts even before it had completed its work. That a constitution prepared by such a convention will be prevented by judicial action from being submitted to the people for adoption was decided in Ellingham v. Dye. ${ }^{73}$

However, contrary to the attitude of the courts toward a specific amendment which has been illegally adopted, the courts ordinarily will not interfere with a constitution which has been approved by the people even if illegally formed, particularly if it has been accepted and acted upon by other departments of the government. The Pennsylvania Convention of 1873 proposed alterations of the Bill of Rights, although such a proposal was beyond its powers by reason of limitations imposed by the enabling act and the vote of the people in electing delegates thereunder. A bill in equity was filed to enjoin the submission of the constitution to the people. It prayed that the act calling the convention be declared unconstitutional and that the convention itself be decreed to be an illegal body and its actions invalid. Various acts were alleged as the bases of the application to the court, one being that the convention had illegally proposed to alter the Bill of Rights. The court, rejecting other arguments, conceded that the convention had exceeded its powers by proposing alterations in the Bill of Rights. However, before the case came before the Supreme Court, the revised constitution had been submitted to the people and approved by a large majority. The court, therefore, at the outset of its opinion said:

"The change made by the people in their political institutions, by the adoption of the proposed Constitution since [the decree of the court below] forbids an inquiry into the merits of this case. The question is no longer judicial . . .." 74

This decision, which in fact upheld a revolutionary change in the Constitution of Pennsylvania, is interesting because it illustrates the truth of the observation, previously stated, that the courts have been liberal in sustaining amendments, even though irregularly made, when the people have approved them either by vote or by acquiescence.

73. 178 Ind. 336, 99 N.E. 1 (1912). It has already been noted that efforts by a convention to step outside of its powers by passing acts of legislation or interfering with the executive department of the state will be enjoined by the courts.

74. Wood's Appeal, 75 Pa. 59, 68 (1874). 
There are other cases which take the same position as the Pennsylvania court, i.e., that if the work of a constitutional convention, although irregularly produced, has been approved or accepted by the people, the court will refuse to interfere on the ground that a political question and not a legal question is involved. In Miller $v$. Johnson, ${ }^{75}$ a constitutional convention in Kentucky submitted its work to the people, who approved it. Thereafter, the convention reassembled and made certain additional alterations in the constitution, which were not submitted to the voters but were promulgated as part of the constitution. These alterations were accepted and acted under by other departments of the government. When the matter came before the Supreme Court, it held that the question was not a judicial but a political one, and dismissed a bill in equity seeking to interfere with those parts of the constitution alleged to have been illegally adopted. A similar decision was made in Taylor $v$. Commonzealth, by which the Virginia court upheld the legality of a constitution because it had been "recognized, accepted and acted upon as the only valid Constitution of the State by the Governor . . . by the Legislature," ${ }^{76}$ and by others. The same view was expressed in Staples $v$. Gilmer, ${ }^{77}$ in which the Court of Appeals of Virginia apparently approved a previous revision of the state constitution because for a period of years it had not been challenged.

Thus, it appears that after the people have spoken by approving a revision of the constitution, or even after they have acquiesced in a change which would have been declared illegal if action had been begun in time, the courts will not disturb it but will treat the matter as a political question which has been laid to rest by the action or acquiescence of the people in whom the supreme power always remains. ${ }^{78}$

75. $92 \mathrm{Ky} .589,18$ S.W. 522 (1892).

76. 101 Va. 829, 831, 44 S.E. 754, 755 (1903).

77. 183 Va. 613, 33 S.E.2d 49 (1945). See also Keenan v. Price, 68 Idaho 423, 195 P.2d 665 (1948); Wheeler v. Board of Trustees, $200 \mathrm{Ga} .323,37$ S.E.2d 322 (1946) ; Loomis v. Jackson, 6 W. Va. 613 (1873); Larkin v. Gronna, 69 N.D. 234, 285 N.W. 59 (1939). But see Huff v. Selber, 10 F.2d 236 (W.D. La. 1925).

78. See Taylor v. King, $284 \mathrm{~Pa} 235,130$ Atl. 407 (1925), in which this rule was applied to specific amendments, illegally adopted, which had been accepted by the people. 